\title{
Target versus Native Language Use in Foreign Language Classes: Perspectives of Students and Instructors
}

\author{
Emrah Ekmekçi ${ }^{1}$ \\ ${ }^{1}$ Faculty of Education, Ondokuz Mayıs University, Samsun, Turkey \\ Correspondence: Emrah Ekmekçi, Faculty of Education, Ondokuz Mayıs University, Samsun, Turkey. Tel: \\ 90-362-312-1919-5152. E-mail: emrah.ekmekci@omu.edu.tr
}

Received: February 15, 2018

Accepted: March 30, $2018 \quad$ Online Published: April 23, 2018

doi:10.5539/ies.v11n5p74

URL: https://doi.org/10.5539/ies.v11n5p74

\begin{abstract}
Whether or not to use students' native language (L1) in second or foreign language classes has always been debated by many scholars and researchers. This controversial issue has taken place in the literature with various case studies and findings. The current study investigates into both students and teachers' perspectives on using L1 in foreign classes. The study was conducted in a state university offering compulsory language education for at least one academic year in three foreign languages, English, German, and French in 2016-2017 academic year. As data collection instruments, two Likert-type questionnaires were administered to instructors and students. Ten English, seven German and three French Language instructors participated in the study together with 217 students from three compulsory foreign language preparatory classes. Descriptive data were analysed in order to determine the students and instructors' perspectives about L1 use. ANOVA test was also used to find out whether there exist significant differences among students and instructors with regard to L1 use. The results reveal that there is a statistically significant difference between English and German language students and between French and German language students with regard to L1 use in the foreign language classrooms. However, there is not a statistically significant difference between English and French language students with regard to L1 use in the foreign language classrooms. The findings also indicate that there is no statistically significant difference among English, French and German language instructors concerning the use of L1 in the classes.
\end{abstract}

Keywords: L1 use, foreign language classes, target language-only policy

\section{Introduction}

Whether to use students' native language (first language or the mother tongue) (L1) in the foreign/second language (L2) classes has always been a controversial issue. While some methods such as Grammar Translation, Silent Way, Desuggestopedia, Community Language Learning, Total Physical Response, and Communicative Language Teaching allow learners to use L1 to a certain or a great extent, other methods like Direct Method, Audio-Lingual Method, Content-Based Instruction and Task-Based Language Teaching encourage learners to use L2 as much as possible. From Grammar Translation to the contemporary methods, the role of L1 in language teaching methods has changed remarkably. In line with this change some institutions and language curricula have started to adopt target language-only policy even banning L1 use in classroom instructions and procedures. The main argument for banning L1 is that it makes students dependent on it. Besides, students do not try to understand the meaning from the context and do not try to produce utterances for communicative purposes in real situations. Limiting or banning the use of L1 also results from the reactions against Grammar Translation Method in which L1 use dominates all language learning process and the purpose of language learning is far from training communicatively competent individuals in target language. With the advent of Direct Method which emphasizes the idea that languages are best learnt in the same way how children learn their mother tongue, oppositions to the use of L1 have become more obvious and accordingly some other methods such as Audio-Lingual Method, Content-Based Instruction and Task-Based Language Teaching have suggested avoiding the use of L1 in foreign/second language classes.

The research with regard to L1 use in foreign/second language education focuses on different dimensions, in particular the amount of L1 use, functions of L1 in L2 learning, and language teachers and learners' perceptions about L1 use in L2 classroom context. When the related literature is reviewed, it is seen that many scholars and researchers in foreign or second language education field have different opinions with regard to L1 use. For instance, target language-dominance has been both criticized and supported by many scholars. Some of the 
scholars are for the use of L1 in L2 classrooms, while some are against. There is also research supporting the judicious use of L1 in the literature.

On one hand, proponents of L1 use in the classroom usually advocate similar reasons. For example, Cook (2010) states that banning L1 contradicts 'the pedagogical principle of moving from known to unknown' (as cited in Larsen-Freeman \& Anderson, 2013, p. 5). Atkinson (1987) emphasizes the relationship between humanistic aspects of language learning and L1 stating that instructors should employ some techniques like translation in which students can take advantage of using their native tongue. Atkinson maintains that $\mathrm{L} 1$ use enables teachers to establish an emotional bond, thus encouraging students to express themselves in English. Giving instructions, developing strategies, and checking comprehension are among the advantages of L1 use (as cited in Ekmekçi, 2015). Likewise, Choffey (2001) enumerates the following reasons for L1 use; (1) Students' L1 is a means of relating the learning activities to the students' experiences. (2) If students come across some specific lexical items between the mother tongue and target language culture, they will learn how to deal with. (3) L1 use enables students to establish a kind of strong relationship between L1 and L2.

Avoidance of L1 in L2 classes is considered to be a political issue and defined by Pennycook (1994) as 'language myths of Europeans' (p. 121). West (1962) states that this avoidance is thought to be due to native speaker teachers of English who do not know students' mother tongue. This causes monolingualism in foreign language learning (as cited in Taşkın, 2011, p. 3). Similarly, several scholars (Atkinson, 1987; Anton \& DiCamilla, 1999; Cook, 2001; Patchler \& Field, 2001; Belz, 2003; Nation, 2003; Macaro, 2005; Edstrom, 2006) believe the importance of using L1 and criticize monolingual approach in which they believe that target language dominance creates tension between learners and teachers causing a psychological barrier.

On the other hand, some scholars (Duff and Polio, 1990; Auerbach, 1993; Macaro, 2001, 2005; Inbar-Lourie, 2010; Hall \& Cook, 2012) are against the use of L1 and advocate the target language only policy arguing that monolingual classrooms enhance intercultural competence of students and students have the opportunity of maximum exposure to the target language. They state that separation and distinction of L1 and L2 lead to successful learning and using L1 in teaching L2 is an obstacle for language learning; hence, it should be abandoned at all costs (as cited in Taşkın, 2011). Moreover, comprehensible input hypothesis by Krashen (1982) supports exposure to the target language as much as possible. The scholars advocating target language only policy also state that the more the learners hear the target language, and are exposed to it, the sooner they will learn and internalize the language.

In addition to the scholars who advocate either bilingual (L1 and L2 use together) or monolingual (target language only), there are some other scholars (Atkinson, 1987; Carless 2008; Storch \& Aldosari , 2010; Ghorbani, 2011; Leeming, 2011; Al-Jadidi \& Sanguinetti, 2011; DiCamilla \& Anton, 2012; Çalış \& Dikilitaş, 2012; Makulloluwa, 2013; Moore, 2013; Adnan, Mohamad, Yusoff, \& Ghazali, 2014; Samar \& Moradkhani, 2014) arguing that flexible and balanced use of L1 in L2 learning contributes a lot to language learning process.

As stated before, one of the dimensions of research conducted with regard to L1 use in foreign/second language setting focuses on language teachers' and learners' perceptions about L1 use. For example, Al Sharaeai (2012) conducts an online survey on 51 participants and finds that students use L1 for a variety of reasons such as for explaining and asking about the new ideas and concepts presented in English classes, for feeling connected to their cultures, and when they cannot find the correct word in English. Likewise, Hashemi and Sabet (2013) examine Iranian EFL teachers and learners' perceptions towards Persian use in English classes. They conclude that students and teachers' views are different from each other in those students are willing to use Persian while teachers tend to use English in the lessons. Teachers think that general medium of instruction must be English and students should use their mother tongue only when they really need it to lower their anxiety level. In another study conducted with Arab and Jewish students, Orland-Barak and Yinon (2005) try to find out the perspectives of 14 Arab and Jewish student teachers towards the use of L1. In the study, student teachers are expected to record, transcribe, and reflect on their teaching experiences. The result of the study shows that both Arab and Jewish student teachers have similar reasons for using L1 in English courses. The researchers determine three categories with regard to L1 use. These categories are as '(1) using L1 for clarification purposes; (2) using L1 for promoting communication in L2 and for enhancing pupil participation; (3) using L1 to assist the novice teacher in managerial aspects of the lesson and in building rapport with the pupils' (p. 98).

In another study, Mohebbi and Alavi (2014) focus on teachers' beliefs and perceptions towards L1 use in EFL context. Seventy-two teachers participate in the study by filling out a questionnaire. The findings of the study reveal that teachers use L1 for mainly providing feedback, explaining grammar, building rapport, teaching lexical items, and saving time in some activities. The researchers also emphasize the facilitative effects of employing L1 
in English classes. In addition to the research cited above, there is much research (Raeiszadeh, Alibakhshi, Veisi, \& Gorjian, 2012; Blackman, 2014; Sa'd, \& Qadermazi, 2015) dwelling upon the role of L1 in L2 classes. Most of the findings of the research with regard to L1 use reveal that L1 is not something that hinders foreign language learning, on the contrary it may be an invaluable source if it is referred to as convenience in the learning process.

The target language-only policy was also popular in foreign language education settings in Turkey. Some institutions followed this policy strictly and enforced the teachers and learners to use the target language as the mere medium of communication while some accepted optimal amount of L1 use in the classrooms. To the best of our knowledge, there are few studies dwelling on the perceptions of students and teachers towards L1 use in Turkish context. For example, Kayaoğlu (2012) aims to explore English teachers' perceptions about the use of L1 in L2 classes. 44 student teachers participate in the study at a state university in Turkey. Data are collected through a questionnaire and interview. The findings of the study indicate that teachers are aware of the possible benefits of L1 use and the more they get experiences, the more they tend to employ it systematically in their classes. In a similar study, Mahmutoğlu and Kicır (2013) conduct a study with 25 instructors of English and 105 students in an EFL context. Students and instructors' perceptions about the use of their mother tongue in L2 classes are determined through a questionnaire and interview. The researchers conclude that students and instructors' native language serves as an intermediator and no significant difference is reported between instructors and students' perceptions on using L1 in their classrooms. Oflaz (2009) also reports no significant difference between instructors and students as to L1 use. Both instructors and students think that mother tongue can be used when needed. Likewise, administering a questionnaire and an interview to 20 instructors and 286 students, Paker and Karaağaç (2015) state that instructors and students are aware of the importance of the use of target language, but they do not deny the need of mother tongue when they need to use it.

The other studies (Yıldırım \& Mersinligil, 2000; Çelik, 2003; Üstünel \& Seedhouse, 2005; Çelik, 2008; Kahraman, 2009; Sarıçoban, 2010; Şenel, 2010; Kayaoğlu, Öztürk, \& Dağ-Akbaş, 2010; Timuçin \& Baytar, 2015) conducted in Turkish EFL context usually focus on the roles and functions of students' mother tongue in English classes, whether the mother tongue should be employed or not, when and why to use the mother tongue, and code-switching practices.

The related literature that has been reviewed so far suggests that there is much research conducted to find out the functions, roles, and effects of L1 use in L2 classes. In addition, there exists research focusing on the beliefs, attitudes, and perceptions of either students or teachers or both. Most of the studies have been conducted in English classes as well. However, there is scarcity of research in Turkish context with regard to students and instructors' perceptions about the use of L1 in English, German, and French language classes. This study aims to fill this gap and is significant since it focuses on not only L1 use in English classes but also in German and French classes as well. It is thought that the findings of the study will be beneficial for language teachers who have been in a dilemma of whether or not to use L1in L2 classes. Our findings may also help teacher educators, materials developers, and syllabus designers in terms of raising their awareness about the functions, roles, and effects of L1 use and exploring students and instructors' perspectives about L1 use in L2 classes. Therefore, our study searches answers for the following research questions:

1) What are English, German and French preparatory class students' perspectives on using L1 in foreign language classes?

2) What are English, German and French language instructors' perspectives on using L1 in foreign language classes?

\section{Method}

The study has a quantitative research design. The population of the study is English, French and German preparatory class students in the tertiary level in Turkey. The sample consists of English, French and German preparatory class students at a state university in Turkey. Convenience sampling type was used in the study. Dörnyei (2007) states that convenience sampling provides researchers with the opportunity to select the members of the target population for the purpose of the study if they meet certain practical criteria.

\subsection{Participants}

Two hundred and seventeen English, French and German preparatory class students participated in the study. Eighty of whom were attending in English language preparatory class, 77 in German language class, and 60 in French language preparatory class in the fall term of 2015-2016 academic year and in the spring term of 2016-2017 academic year. In addition, 20 foreign language instructors were given the questionnaire on target language-only policy. Ten of whom were English language instructors, seven were German, and three were French language 
instructors teaching at preparatory language classes in a state university in Turkey.

\subsection{Instrument}

The study employed a questionnaire (for students) developed by Hashemi and Sabet (2013). The questionnaire had originally 26 items with 4-point Likert-type scale. In the questionnaire, two items were deleted and transformed into 5-point Likert-type scale as it did not fit into the context of the study. The students were expected to rate from 1 (strongly agree) to 5 (strongly disagree). Three of the items $(7,12,15)$ were reverse coded in the course of analysing the data. The Cronbach alpha coefficient was calculated .771 after the adaptation. In the study, another questionnaire (for instructors) developed by Mohebbi and Alavi (2014) was also used. The Cronbach alpha coefficient was calculated .928. Both questionnaires have been piloted and modified consulting two experts in survey development.

\subsection{Data Analysis}

Data have been analysed using SPSS 20 software. Frequency analysis has been conducted to find out the mean scores of students and instructors for English, German, and French classes separately. In addition, ANOVA analysis has been used to determine the differences among group means. Descriptive data and ANOVA results regarding the three language classes and their perspectives about L1 use are presented in the following section.

\section{Results}

The students in English, German, and French language classes responded to the target-language only policy survey which had 24 items. The mean scores of each class are presented in Table 1 below.

Table 1. Students' mean scores with regard to 11 use in English/German/French classes

\begin{tabular}{|c|c|c|c|}
\hline & $\begin{array}{c}\text { English } \\
n: 80\end{array}$ & $\begin{array}{c}\text { German } \\
n: 77\end{array}$ & $\begin{array}{c}\text { French } \\
n: 60\end{array}$ \\
\hline 1. I like it when teachers use Turkish in the classroom to explain grammar rules. & 2.02 & 1.50 & 1.90 \\
\hline $\begin{array}{l}\text { 2. I like when teachers use Turkish for classroom management (e.g. giving } \\
\text { instructions and groupings students). }\end{array}$ & 2.51 & 1.77 & 2.55 \\
\hline $\begin{array}{l}\text { 3. I like when teachers use Turkish in the classroom to explain the meaning of a } \\
\text { new vocabulary. }\end{array}$ & 2.22 & 1.67 & 2.58 \\
\hline $\begin{array}{l}\text { 4. When teachers use Turkish in the classroom, students will tend to speak more } \\
\text { Turkish than English/German/French in the classroom. }\end{array}$ & 2.12 & 2.96 & 2.48 \\
\hline $\begin{array}{l}\text { 5. The more the English/German/French teacher makes use of Turkish, the less } \\
\text { effort students make to understand the teacher's use of English/German/French. }\end{array}$ & 2.13 & 2.75 & 2.21 \\
\hline $\begin{array}{l}\text { 6. I like when teachers use English/German/French for explaining simple } \\
\text { grammatical terms and concepts and Turkish for more difficult terms and } \\
\text { concepts. }\end{array}$ & 3.93 & 1.63 & 2.00 \\
\hline $\begin{array}{l}\text { 7. Teachers should not use Turkish in English/German/French classrooms because } \\
\text { it reduces the amount of students' exposure to English. }\end{array}$ & 2.73 & 2.63 & 3.40 \\
\hline 8. The use of Turkish should be minimized in the classroom. & 2.17 & 2.92 & 2.28 \\
\hline $\begin{array}{l}\text { 9. The only way to learn an English/German/French Word completely is to know } \\
\text { its meaning in Turkish. }\end{array}$ & 2.98 & 2.16 & 3.10 \\
\hline $\begin{array}{l}\text { 10. I like it when teachers ask me to translate a word or sentence into Turkish as a } \\
\text { comprehension check. }\end{array}$ & 2.23 & 1.74 & 2.15 \\
\hline $\begin{array}{l}\text { 11. I like it when my teacher uses English/German/French to give homework in } \\
\text { the classroom. }\end{array}$ & 3.68 & 2.40 & 2.68 \\
\hline $\begin{array}{l}\text { 12. I do not like the use of Turkish because it prevents me from thinking in } \\
\text { English. }\end{array}$ & 2.60 & 2.53 & 3.15 \\
\hline 13. I sometimes speak Turkish to my classmates to clarify teacher's directions. & 2.03 & 1.72 & 2.35 \\
\hline 14. When students speak Turkish in the classroom, it makes me disappointed. & 2.56 & 3.88 & 3.16 \\
\hline $\begin{array}{l}\text { 15. I never feel quite sure of myself when students and teachers speak } \\
\text { English/German/French in the class. }\end{array}$ & 3.30 & 2.81 & 2.66 \\
\hline 16. The use of Turkish in the classroom reduces students' anxiety. & 2.70 & 2.40 & 3.05 \\
\hline $\begin{array}{l}\text { 17. It frightens me when I do not understand what the teacher is saying in } \\
\text { English/German/French in the classroom. }\end{array}$ & 2.70 & 2.54 & 2.65 \\
\hline 18. The medium of instruction should be English/German/French in the class. & 2.20 & 2.53 & 2.13 \\
\hline
\end{tabular}




\begin{tabular}{|c|c|c|c|}
\hline 19. I feel more comfortable when I talk to my teacher in Turkish. & 2.53 & 2.20 & 2.70 \\
\hline 20. I can understand the lesson much better if the teachers use Turkish. & 2.97 & 2.19 & 3.00 \\
\hline $\begin{array}{l}\text { 21. Turkish can help me to express my feelings and ideas that I cannot explain in } \\
\text { English/German/French. }\end{array}$ & 2.23 & 1.66 & 2.55 \\
\hline 22. I prefer to ask my teacher questions in Turkish. & 2.88 & 2.20 & 2.78 \\
\hline $\begin{array}{l}\text { 23. It is necessary to explain the differences and similarities between Turkish and } \\
\text { English/German/French in Turkish. }\end{array}$ & 2.47 & 2.00 & 2.45 \\
\hline 24. I prefer to use bilingual dictionaries. & 2.21 & 1.94 & 2.55 \\
\hline
\end{tabular}

1. Strongly Agree; 2. Agree; 3. Neutral; 4. Disagree; 5. Strongly Disagree

As it is seen in Table 1, most of the items were responded in favour of L1 use in foreign language classes. Students in three classes declared that they expected teachers to use L1 especially while explaining grammar rules, the meaning of new words, the differences and similarities between Turkish and target languages, checking comprehension, giving homework, and translating a word or sentence as a comprehension check. German language students were in favour of L1 use in more cases than English and French language students. For example, compared to their English and French counterparts, they were more inclined to agree that teachers should use L1 in case of difficult grammatical rules (m: 1.50), new vocabulary (m:1 .67), comprehension check (m: 1.74), and classroom management (m: 1.77). Similarly, German language students advocated students' use of L1 more strictly than English and French language students with regard to clarifying teachers' directions (m: 1.72) and expressing their feelings (m: 1.66). As to the language preferences, German students (m: 1.94) had more tendency than English and French students to use bilingual dictionaries. For most of the items, almost all of the students in each class were in favour of L1 use; however, French and English language students remained neutral about relationship between teachers' use of Turkish and understating the lesson better. In addition, French language students were more inclined to disagree for the items 7, 9, 12,14, 16 and similarly English language students for the items $6,11,15$. On the other hand, German students were in disagreement with the item 14, which was related to students' using Turkish that caused disappointment. Students' average tendency to use L1 was also important in three classes as well. Table 2 indicates mean scores of students for the whole questionnaire.

Table 2. Overall mean scores of English, German, and French language students

\begin{tabular}{lccc}
\hline Class & $\mathrm{N}$ & Mean & Std. Deviation \\
\hline English & 80 & 2.59 & .34916 \\
German & 77 & 2.28 & .31320 \\
French & 60 & 2.60 & .39873 \\
Total & 217 & 2.48 & .38092 \\
\hline
\end{tabular}

As shown in the table above, German language students have more tendencies to use L1 in lessons than English and French language students. This may be contributed to lots of things including students' linguistic background, expectations, experiences, affective filters, motivations, and so on. This may also be because of German language students' perceptions concerning the complexity of German language. As for the differences between the groups, Anova test results are presented in Table 3 below:

Table 3. Anova results for the differences of L1 use among English, German, French language students

\begin{tabular}{ccccc}
\hline \multicolumn{2}{c}{ Classes } & Mean Difference & Std Error & Sig.* \\
\hline \multirow{4}{*}{ English } & German & .3070 & .0561 & .000 \\
& & & & \\
& French & -.0140 & .0600 & .970 \\
& English & -.3070 & .0561 & .000 \\
German & & & & \\
& French & -.3210 & .0605 & .000 \\
& English & .0140 & .0600 & .970 \\
French & & & & \\
& German & .3210 & .0605 & .000 \\
\hline
\end{tabular}

* The mean difference is significant at the 0.05 level. 
It is clear from Table 3 that there is a statistically significant difference between English and German language students and between French and German language students with regard to L1 use in the foreign language classrooms. However, there is not a statistically significant difference between English and French language students with regard to L1 use in the foreign language classrooms. These findings mean that German language students' perspectives towards L1 use are different from English and French language students in that German language students have a more strict view in favour of L1 use in foreign language classes. Perceived difficulty of German language compared with English and French languages can constitute one of the reasons of German language students' insistence on more L1 use in the classroom. In addition, the popularity of English in Turkey and possible similarities between English and French languages may have an effect on students' opinions regarding the use of L1 or L2 in the classrooms.

The research also attempts to find out instructors' perspectives about L1 use as well. To this end, a similar questionnaire has been employed for 20 foreign language instructors of English, French, and German. The descriptive findings are presented in Table 4 below.

Table 4. Instructors' mean scores with regard to L1 use in English/German/French classes

\begin{tabular}{|c|c|c|c|}
\hline & English & German & French \\
\hline 1. I use learners' L1 to teach new vocabulary. & 3.00 & 3.42 & 3.66 \\
\hline 2. I employ learners' L1 to explain grammar. & 2.70 & 2.42 & 3.33 \\
\hline 3. I use learners' L1 to provide clarification when learners do not understand in L2. & 2.40 & 2.85 & 2.33 \\
\hline 4. I use learners' $\mathrm{L} 1$ to provide feedback and explain their errors. & 2.70 & 2.57 & 2.33 \\
\hline 5. I use learners' L1 in giving written corrective feedback on learners' compositions. & 4.40 & 3.71 & 3.00 \\
\hline 6. I use learners' $\mathrm{L} 1$ to explain instructions for assignments or projects. & 3.20 & 3.00 & 2.33 \\
\hline $\begin{array}{l}\text { 7. I use learners' } \mathrm{L} 1 \text { to give meta-linguistic knowledge, in particular about discussing the tasks, such as the } \\
\text { objective and the steps of tasks. }\end{array}$ & 3.10 & 2.57 & 2.00 \\
\hline 8. I use learners' L1 to negotiate the syllabus and the lesson. & 3.50 & 2.00 & 1.66 \\
\hline 9. I use learners' L1 in administrative issues like exam announcement. & 3.50 & 1.85 & 2.00 \\
\hline 10. I use learners' $\mathrm{L} 1$ in dealing with discipline problems in class. & 2.80 & 1.85 & 2.00 \\
\hline 11. I use learners' $\mathrm{L} 1$ to establish or assert authority. & 3.30 & 3.14 & 2.66 \\
\hline 12. I use learners' $L 1$ at the end of the class to answer possible questions. & 3.40 & 3.28 & 3.00 \\
\hline 13. I use learners' $\mathrm{L} 1$ to encourage and comfort learners. & 3.30 & 2.71 & 3.33 \\
\hline 14. I use learners' $L 1$ to build rapport with learners. & 2.90 & 2.57 & 3.33 \\
\hline 15. I use learners' $\mathrm{L} 1$ in giving personal comments. & 3.00 & 2.57 & 2.33 \\
\hline 16. I use learners' $L 1$ in making humorous comments. & 3.20 & 2.57 & 3.33 \\
\hline $\begin{array}{l}\text { 17. I use learners' L1 in presenting information about the target culture, in particular discussing } \\
\text { cross-cultural issues. }\end{array}$ & 3.20 & 2.85 & 3.33 \\
\hline 18. I take advantage of learners' L1 to supervise and guide them when they perform a task collaboratively. & 3.50 & 2.57 & 2.66 \\
\hline 19. I employ learners' $L 1$ to conduct pre-task activities, namely pre-listening and pre-reading. & 4.30 & 3.85 & 3.33 \\
\hline 20. I use learners' L1 in giving individual help to learners. & 3.30 & 2.71 & 2.00 \\
\hline 21. I use learners' $L 1$ to save time in lengthy task explanations. & 3.40 & 2.85 & 3.00 \\
\hline 22. I use learners' L1 in making contrast between L1 and L2. & 2.70 & 2.57 & 3.33 \\
\hline
\end{tabular}

1. Strongly Agree; 2. Agree; 3. Neutral; 4. Disagree; 5. Strongly Disagree

Table 4 makes it clear that most of the instructors were usually in favour of using L1 for explaining grammar, providing feedback and clarification, negotiating the syllabus, announcing administrative issues, dealing with discipline problems, building rapport with learners, and making contrasting between L1 and L2. French language instructors were slightly more inclined to use L1 compared to English and German language instructors. For example, they declared that they used L1 for explaining instructions for assignments or projects (m: 2.33), giving meta-linguistic knowledge ( $\mathrm{m}: 2.00)$, negotiating the syllabus and the lesson (m: 1.66), establishing authority (m: 2.66), giving personal comments ( $\mathrm{m}: 2.33$ ), and giving individual help to learners ( $\mathrm{m}: 2.00$ ). Besides these positive attitudes towards L1 use in L2 classes, findings revealed that some instructors were opposed to the use of L1. For instance, English and German language instructors stated that they were against the use of L1 while giving written corrective feedback on learners' compositions and conducting pre-task activities. In addition, French and German instructors interestingly disagreed to use L1 while teaching new words. The mean scores are presented in Table 5 
below:

Table 5. Overall mean scores of English, German, and French language instructors

\begin{tabular}{lccc}
\hline Class & $\mathrm{N}$ & Mean & Std. Deviation \\
\hline English & 10 & 3.21 & .63845 \\
German & 7 & 2.75 & .68427 \\
French & 3 & 2.74 & .41244 \\
Total & 20 & 2.48 & .144322 \\
\hline
\end{tabular}

Table 5 above shows that French and German language instructors are more inclined to use L1 than English language instructors. The reason for that can be attributed to the limited use of German and French compared with English in foreign language setting in Turkey. It is known that English language learners have more opportunity outside the classroom to be exposed to the target language than French and German students. Therefore, instructors of German and French may prefer L1 use more frequently than the instructors of English to keep the students engaged and motivated as much as possible in $\mathrm{L} 2$ classes.

The differences among the instructors of English, German, and French with regard to the use of L1 are statistically indicated in the following Table 6.

Table 6. Anova results for the differences of L1 use among English, German, French language instructors

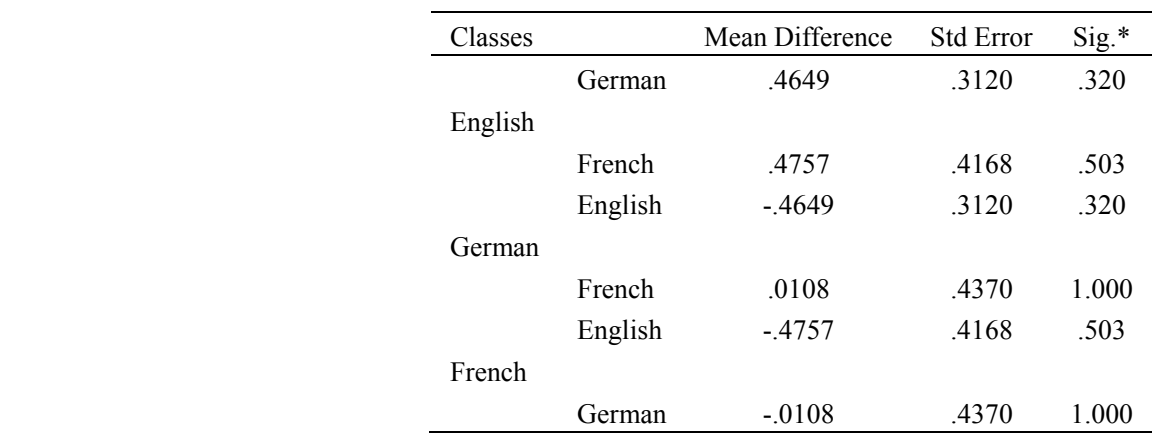

* The mean difference is significant at the 0.05 level.

As it is clear in Table 6, there is no statistically significant difference among English, French and German language instructors concerning the use of $\mathrm{L} 1$ in the classes. This means that foreign language instructors in Turkish foreign language setting in the current study, limited to the chosen sample, have similar perspectives on L1 use. In addition, the findings indicate that different languages in foreign language setting do not have an influence on how instructors perceive the use of L1 in L2 classes.

\section{Discussion and Conclusion}

The study aims to explore English, French, and German language students and instructors' perspectives towards L1 use in foreign language classes. To this end, two different questionnaires have been employed for students and instructors separately. Two hundred and seventeen students and 20 instructors participated in the study conducted in a state university in Turkey. The findings indicate that there is a statistically significant difference between English and German language students and between French and German language students with regard to L1 use in the foreign language classrooms. However, there is not a statistically significant difference between English and French language students with regard to L1 use in the foreign language classrooms. The findings also reveal that there is no statistically significant difference among English, French and German language instructors concerning the use of L1 in the classes.

Descriptive statistics show that students in three classes expect teachers to use L1 especially while explaining grammar rules, the meaning of new words, the differences and similarities between Turkish and target languages, checking comprehension, giving homework, and translating a word or sentence as a comprehension check. Students in German class are in favour of L1 use in more cases than English and French language students. German language students' insistence on the use of L1 more than English and French language students may depend upon the relative complexity of German language, as a result of which students need more explanations in 
the native language. Besides, there exists a mismatch between the perspectives of German language students and instructors. German language students demand more L1 use even if the instructors state that they use L1 when necessary, which is similar to English and French counterparts. It is thought that this mismatch does not create remarkable problems in the classroom setting since the instructors' responses seem to be flexible enough for the use of L1.

The study reveals similar results with some of the research in the literature. For example, Al Sharaeai's (2012) study has shown that students use L1 for explaining and asking about the new ideas and concepts presented in English classes, for feeling connected to their cultures, and for learning new words, which are identical findings with our study. The study is also similar to Mohebbi and Alavi's (2014) findings in terms of instructors' perspective. As in the case in our study, instructors usually use L1 for mainly providing feedback, explaining grammar, building rapport, and teaching lexical items. The results of the study are identical with those conducted in Turkey as well. The findings of the studies by Oflaz (2009), Kayaoğlu (2012), and Paker and Karaağaç (2015) reveal that instructors and students are aware of the possible benefits of L1 use and they use it whenever they need for specific occasions in the foreign language class. Contrary to the studies which have similar findings, Hashemi and Sabet's (2013) study differs from the current one in that students and teachers' views are different from each other. In their study, they state that students are willing to use Persian while teachers tend to use English in the lessons. However, the current study reveals that there is no considerable difference between students and instructors' perspectives regarding the use of L1.

The results of the study are significant for several reasons. First, to our knowledge, there is no other study with its design comparing three foreign language classes in different languages with regard to L1 use in the class. The findings make it clear the similar and different perspectives of students and instructors of these three foreign languages in Turkey. Second, the study investigates the perspectives of both students and instructors about L1 use. Thus, the perceptions of both students and instructors can be compared and contrasted in order to determine the correct time and functions to use L1 in foreign language classes. Next, with its findings, the study can shed light on teacher educators, materials and syllabus designers, and language teachers in terms of preparing and designing language materials and training prospective foreign language teachers with the awareness of potential benefits of L1 use.

\section{References}

Adnan, M., Mohamad, S., Yusoff, M. A., \& Ghazali, Z. (2014). Teachers' Attitudes towards the Use of First Language in Arabic Classroom. Researchers World, 2, 20-28.

Al Sharaeai, W. (2012). Students' perspectives on the use of L1 in English classrooms (Unpublished doctoral dissertation). Iowa State University, Ames, Iowa.

Al-Jadidi, H., \& Sanguinetti, J. (2011). The Judicious Use of L1 in the EFL Contexts. International Journal of Arts \& Sciences, 4(24), 85-92.

Anton, M., \& DiCamilla, F. (1999). Socio-cognitive functions of LI collaborative interaction in the L2 classroom. Canadian Modern Language Review, 83, 233-247. https://doi.org/10.1111/0026-7902.00018

Atkinson, D. (1987). The mother tongue in the classroom: A neglected resource? ELT Journal, 41(4), 241-247. https://doi.org/10.1093/elt/41.4.241

Auerbach, E. (1993). Re-examining English only in the ESL classroom. TESOL Quarterly, 27(1), 9-32. https://doi.org/10.2307/3586949

Belz, J. A. (2003). Identity, deficiency \& firsty language use in foreign language education. In C. Blyth (Ed.), The sociolinguistics of foreign language classrooms: Contributions of the native, the near native and the non-native speaker (pp. 209-248). Boston: Thomson Heinle.

Blackman, N. (2014). EFL teachers' perceptions on the use of L1 in a primary and secondary classroom in Belarus (Unpublished master's thesis). University of Edinburgh, Edinburg, Great Britain.

Çalış, E., \& Dikilitaş, K. (2012). The use of translation in EFL classes as L2 learning practice. Procedia-Social and Behavioral Sciences, 46, 5079-5084. https://doi.org/10.1016/j.sbspro.2012.06.389

Carless, D. (2008). Student use of the mother tongue in the task-based classroom. ELT Journal, 62(4), 331-338. https://doi.org/10.1093/elt/ccm090

Çelik, M. (2003). Teaching vocabulary through code-mixing. ELT Journal, 57(4), 361-369. https://doi.org/10.1093/elt/57.4.361 
Çelik, S. (2008). Opening the Door: An Examination of Mother Tongue Use in Foreign Language Classrooms. Hacettepe University, Journal of Education, 34, 75-85.

Choffey, S. (2001). The L1 culture in the L2 classroom. Modern English Teacher, 10(2), 54-58.

Cook, G. (2010). Translation in language teaching: An argument for reassessment. Oxford: Oxford University Press.

Cook, V. (2001). Using the first language in the classroom. The Canadian Modern Language Review, 57(3), 402-423. https://doi.org/10.3138/cmlr.57.3.402

DiCamilla, F. J., \& Anton, M. (2012). Functions of L1 in the collaborative interaction of beginning and advanced second language learners. International Journal of Applied Linguistics, 22(2), 160-188. https://doi.org/10.1111/j.1473-4192.2011.00302.x

Dörnyei, Z. (2007). Research methods in applied linguistics: quantitative, qualitative and mixed methodologies. Oxford: Oxford University Press.

Duff, P. A., \& Polio, C. G. (1990). How much foreign language is there in foreign language classroom? The Modern Language Journal, 74(2), 154-156. https://doi.org/10.1111/j.1540-4781.1990.tb02561.x

Edstrom, A. (2006). L1 use in the L2 classroom: One teacher's self-evaluation. Canadian Modern Language Review, 63(2), 275-292. https://doi.org/10.3138/cmlr.63.2.275

Ekmekçi, E. (2015). L1 Use in Individual Conferencing and Its effects on EFL Students' Writing Performances. International Journal of Languages' Education and Teaching, Special Issue, 723-733. https://doi.org/10.18298/ijlet.283

Ghorbani, A. (2011). First Language Use in Foreign Language Classroom Discourse. Procedia-Social and Behavioral Sciences, 29, 1654-1659. https://doi.org/10.1016/j.sbspro.2011.11.408

Hall, G., \& Cook, G. (2012). Own-language use in language teaching and learning. Language Teaching, 45(3), 271-308. https://doi.org/10.1017/S0261444812000067

Hashemi, S. M., \& Sabet, M. K. (2013). The Iranian EFL students' and teachers' perception of using Persian in general English classes. International Journal of Applied Linguistics and English Literature, 2(2), 142-152. https://doi.org/10.7575/aiac.ijalel.v.2n.2p.142

Inbar-Lourie, O. (2010). English only? The linguistic choices of teachers of young EFL learners. International Journal of Bilingualism, 14(3), 351-367. https://doi.org/10.1177/1367006910367849

Kahraman, A. (2009). The role of the mother tongue in fostering affective factors in ELT classrooms. Journal of English as an International Language, 5, 107-128.

Kayaoğlu, M. N. (2012). The use of mother tongue in foreign language teaching from teachers' practice and perspective. Pamukkale University Journal of Faculty of Education, 32(2), 25-35.

Kayaoğlu, M. N., Öztürk, Z., \& Dağ-Akbaş, R. (2010). L1 use in EFL classroom: The attitudes of students. In K. Dinçay, İ. H. Erten, E. Zehir-Topkaya, \& A. Yavuz (Eds.), The $6^{\text {th }}$ International ELT Research Conference Proceedings: Current trends in SLA research and language teaching (pp. 401-407). Selçuk, İzmir: Çanakkale Onsekiz Mart University.

Krashen, S. (1982). The Input Hypothesis: An Update. In Georgetown University Round Table on Languages and Linguistics (GURT): Linguistics and Language Pedagogy: The State of the Art, 238.

Larsen-Freeman, D., \& Anderson, M. (2013). Techniques and Principles in Language Teaching 3rd edition-Oxford Handbooks for Language Teachers. Oxford university press.

Leeming, P. (2011). Japanese high school students' use of L1during pair-work. International Journal of Applied Linguistics, 21(3), 360-382. https://doi.org/10.1111/j.1473-4192.2011.00284.x

Macaro, E. (2001). Analyzing student teachers' code-switching in foreign language classrooms: Theories and decision making. Modern Language Journal, 85(4), 531-548. https://doi.org/10.1111/0026-7902.00124

Macaro, E. (2005). Codeswitching in the L2 classroom: A communication and learning strategy. In E. Llurda (Ed.), Non-native language teachers: Perceptions, challenges \& contributions to the profession (pp. 63-84). Boston: Springer. https://doi.org/10.1007/0-387-24565-0_5

Mahmutoğlu, H., \& Kıcır, Z. (2013). The use of mother tongue in EFL classrooms. Lefke European University Journal of Social Sciences, 4(1), 49. 
Makulloluwa, E. (2013). Code Switching by Teachers in the Second Language Classroom. International Journal of Arts \& Sciences, 6(3), 581-598.

Mohebbi, H., \& Alavi, S. M. (2014). Teachers' First Language Use in Second Language Learning Classroom Context: A Questionnaire-based Study. Bellaterra Journal of Teaching \& Learning Language \& Literature, 7(4), 57-73.

Moore, P. J. (2013). An Emergent Perspective on the Use of the First Language in the English-as-a-Foreign-Language Classroom. The Modern Language journal, 97(1), 239-253. https://doi.org/10.1111/j.1540-4781.2013.01429.x

Nation, P. (2003). The role of the first language in foreign language learning. Asian EFL Journal, 5(2), 1-8.

Oflaz, Ö. (2009). Teachers and students' views on using mother tongue in ELT classrooms (a case study at Gaziantep University) (Unpublished master's thesis). University of Gaziantep. Retrieved from http://www.tez2.yok.gov.tr

Orland-Barak, L., \& Yinon, H. (2005). Different but similar: Student teachers' perspectives on the use of L1 in Arab and Jewish EFL classroom settings. Language, Culture and Curriculum, 18(1), 91-113. https://doi.org/10.1080/07908310508668735

Pachler, N., \& Field, K. (2001). Learning to Teach Modern Foreign Languages in the Secondary School. Routledge: London. https://doi.org/10.4324/9780203470190

Paker, T., \& Karaağaç, Ö. (2015). The use and functions of mother tongue in EFL classes. Procedia-Social and Behavioral Sciences, 199, 111-119. https://doi.org/10.1016/j.sbspro.2015.07.494

Pennycook, A. (1994). The Cultural Politics of English as an International Language. Longman: London \& New York.

Raeiszadeh, A., Alibakhshi, G., Veisi, E., \& Gorjian, B. (2012). Iranian EFL learners' perception of the use of L1 to L2 translation task in general English classes. Advances in Asian Social Science, 2(2), 436-440.

Sa'd, S. H. T., \& Qadermazi, Z. (2015). L1 Use in EFL Classes with English-only Policy: Insights from Triangulated Data. CEPS Journal: Center for Educational Policy Studies Journal, 5(2), 159.

Samar, R. G., \& Moradkhani, S. (2014). Codeswitching in the Language Classroom: A Study of Four EFL Teachers' Cognition. RELC Journal, 45(2), 151-164. https://doi.org/10.1177/0033688214534796

Sarıçoban, A. (2010). Should native language be allowed in foreign language classes? Eurasian Journal of Educational Research, 38, 164-178.

Şenel, M. (2010). Should foreign language teaching be supported by mother tongue? Journal of Language and Linguistic Studies, 6(1), 110-120.

Storch, N., \& Aldosari, A. (2010). Learners' use of first language (Arabic) in pair work in an EFL class. Language Teaching Research, 14(4), 355-375. https://doi.org/10.1177/1362168810375362

Taşkın, A. (2011). Perceptions on using L1 in language classrooms: A case study in a Turkish private university (Unpublished master's thesis). Middle East Technical University, Ankara, Turkey.

Timuçin, M., \& Baytar, I. (2015). The functions of the use of L1: insights from an EFL classroom. Kastamonu Education Journal, 23(1), 241-245.

Üstünel, E., \& Seedhouse, P. (2005). Why that, in that language, right now? Code-switching and pedagogical $\begin{array}{llll}\text { focus. International Journal of Applied Linguistics, } & 15(3), & 302-325 .\end{array}$ https://doi.org/10.1111/j.1473-4192.2005.00093.x

West, M. (1962). Teaching English in Difficult Circumstances. Teaching English as a Foreign Language with Notes on the Techniques of Textbook Construction. London: Longman

Yıldırım, R., \& Mersinligil, G. (2000). Use of mother tongue in ELT classes: When and why? Çukurova University Journal of Social Sciences Institute, 6(6), 131-142.

\section{Note}

Note 1 . This study is the extended and revised version of the paper presented in $3^{\text {rd }}$ Çukurova International ELT Teachers Conference (CUELT 2017) hosted by Çukurova University on 20-21 April 2017, Adana, Turkey. 


\section{Copyrights}

Copyright for this article is retained by the author(s), with first publication rights granted to the journal.

This is an open-access article distributed under the terms and conditions of the Creative Commons Attribution license (http://creativecommons.org/licenses/by/4.0/). 